\title{
Dos contratos bancários
}

\author{
Carlos Silveira Noronha*
}

\section{NOÇÕES PRELIMINARES}

Ao tratar dos contratos bancários, há que se ter em mente que essas relações jurídicas negociais são realizadas no âmbito de uma entidade empresária, que desde os mais remotos tempos é denominada BANCO e que modernamente, no direito pátrio, insere-se no contexto das instituições financeiras, assim definidas na chamada Lei da Reforma Bancária (Lei 4.595/64, arts. 17-18).

É o Banco uma entidade empresária que exerce papel de transcendental importância e que se posta no complexo negocial como expressivo pólo de irradiação da atividade econômicofinanceira, sob a tutela do Direito Mercantil e mais especificamente do
Direito Bancário, que se destaca como ramo especial do primeiro.

A conceituação dessa instituição financeira, vem provocando as mais variadas preferências dos comercialistas e, notadamente, dos especialistas em Direito Bancário, seja na qualidade de promotora da circulação monetária, seja como mobilizadora ou intermediadora da expansão do crédito às pessoas físicas e jurídicas que deste necessitam para o desenvolvimento dos seus negócios.

Já em tempos modernos, Vivante definiu o BANCO como "estabelecimento comercial que recolhe os capitais para distribuí-los sistematicamente com operações de crédito" "ao passo que Carvalho de Mendonça refere que os Bancos são "empresas comerciais, cujo

* Professor Titular da Faculdade de Direito da UFRGS e da Faculdade de Direito São Judas Tadeu de Porto Alegre; Mestre e Doutor em Direito pela U.S.P.; Diretor da Revista da Faculdade de Direito da UFRGS.

1 VIVANTE, Cesare. Tratado di Diritto Commerciale, vol. 1, p.92, Milão, 1992. 
objetivo principal consiste na intromissão entre os que dispõem de capitais e os que precisam obtê-los, isto é, em receber e concentrar capitais para sistematicamente distribuí-los por meio de operações de crédito". ${ }^{2}$

Finalmente, para Fran Martins, ao entender que a função dos Bancos supera a de simples intermediários do crédito, refere que "na realidade, os Bancos são mobilizadores do crédito, agindo sempre como sujeitos das operações e dos contratos que realizam", razão por que os conceitua como "empresas comerciais que têm por finalidade realizar a mobilização do crédito, principalmente mediante o recebimento, em depósito, de capitais de terceiros, e o empréstimo de importâncias, em seu próprio nome, aos que necessitam de capital". ${ }^{3}$

No Brasil, na atualidade, os Bancos encontram-se incluídos no elenco das instituições financeiras (lei 4.595, de 31.12.1964). chamada Lei da Reforma Bancária, cujo artigo 17 as define como "pessoas jurídicas públicas ou privadas, que tenham como atividade principal ou acessória a coleta, intermediação ou aplicação de recursos financeiros próprios ou de terceiros, em moeda nacional ou estrangeira, e a custódia de valor de propriedade de terceiros", de modo que esse dispositivo legal não estabelece qualquer diferença entre instituições financeiras e Bancos, mas ao contrário, equipara-os como gênero e espécie.

O parágrafo único, do artigo 17 , da lei especial referida, atribui às pessoas físicas a qualidade de instituições financeiras, equiparando-as às pessoas jurídicas, quando aquelas exercerem qualquer das atividades próprias dessa categoria financeira.

No entendimento da doutrina, há que se estabelecer a distinção entre Bancos e instituições financeiras, caracterizando-se os primeiros como instituições financeiras bancárias propriamente ditas, que criam moeda escritural, e as segundas, como instituições financeiras não bancárias, que apenas influem na velocidade de circulação da moeda. ${ }^{4}$

É pacífico na doutrina que a distinção entre Banco e instituição financeira ainda se torna mais clara no que pertine aos fundos de que dispõem esses dois tipos de organismos financeiros para realizar suas operações. Os Bancos operam não só com seus próprios capitais, mas também com os fundos de toda ordem que recebem do público a título de depósitos, aplicações e outros, ao passo que as instituições financeiras

2 CARVALHO DE MENDONÇA, J. X. Tratado de Direito Comercial Brasileiro, vol. 7, $3^{\mathrm{a}}$ parte, p.119, Rio, 1947.

3 MARTINS, Fran. Contratos e Obrigações Comerciais, n 370, p.407, 14.ed., Forense, Rio, 1996.

4 ABRÃO, Nelson. Direito Bancário, nº 02, p.3, 10.ed., Saraiva, São Paulo, 2007; MARTINS, Fran. Contratos e Obrigações Comerciais, cit., p.497. 
não podem operar senão com seus próprios capitais, pois não lhes permite a lei receber outros aportes de terceiros. Assim sendo, as operações das instituições financeiras não bancárias são mais limitadas que as dos Bancos. ${ }^{5}$

Dos Bancos, distinguem-se também as casas Bancárias, que embora incluam-se no rol das instituições financeiras, daqueles se diferenciam, seja pelo seu capital menor, seja pelo número mais reduzido de suas atividades, cuja existência ocorreu em época de menor pujança econômica, havendo as mesmas desaparecido ou se transformado em Bancos.

Apenas para registrar a presença histórica das Casas Bancárias no complexo econômico-financeiro, traz-se à baila o Decreto n ${ }^{\circ}$ 14.728, de 16.03.1921, que as define e as distingue dos Bancos, ao referir que: "Para os efeitos do presente regulamento, considera-se Banco a pessoa natural ou jurídica que, com capital superior a quinhentos mil cruzeiros (moeda da época), realizar as operações especificadas neste artigo, e Casa Bancária a que, com o mesmo objetivo, tiver o capital igual ou inferior a quinhentos mil cruzeiros". Esse critério quantitativo do capital foi mantido pelo Decreto-lei 6.429, de 13.04.1944, mas a ele foi acrescida a importância econômica das praças em que a Casa Bancária estiver sediada. ${ }^{6}$

\section{FONTES E EVOLUÇÃO HISTÓRICA DOS BANCOS}

Desde as épocas mais recuadas no tempo, notadamente a partir do século VI a.C., começaram a surgir estas práticas negociais realizadas por instituições, nas quais pode-se identificar a presença dos Bancos, sabendo-se, por exemplo, que o empréstimo em dinheiro realizava-se com freqüência, já nessa época, na Babilônia, Egito e Fenícia. ${ }^{7}$

Foi, porém, no mundo grecoromano, chamado antiguidade clássica, que se tornaram conhecidas outras operações que, com as modificações sofridas no transcurso dos tempos, estão atualmente integradas no comércio bancário, não só as que figuram no vasto elenco das modalidades de empréstimo, classificadas como operações ativas, como também no das passivas, em que o Banco figura como obrigado, e, ainda, nas que atua como mero prestador de serviços chamadas operações acessórias ou complementares. Deve-se observar que, embora possa constituir uma situação incomum na concepção dos tempos atuais, esses negócios bancários da época realizavam-se no interior dos templos, seu inicial e verdadeiro berço,

5 ABRÃO, Nelson. Direito Bancário, cit., nº 02, p.5.

6 ABRÃO, Nelson. Direito Bancário, ob. cit., nº 13, p.32-33.

7 MOLLE, Giacomo. I Contratti Bancari, p.4-5, Milão, 1973. 
local onde os antigos reuniam-se para cultuar seus deuses, sendo esse fato compreensível em face dos costumes então vigentes. ${ }^{8}$

Na Idade Média, com o florescimento do comércio, graças às feiras das cidades italianas, surgiam os compsores ou combiatores, que praticavam a troca manual da moeda. Com o aperfeiçoamento de suas atividades; que evoluíram da simples troca de moedas para a atividade creditícia, tornaram-se conhecidos por banqueiros, no século XII, esses cambistas.

Faziam esses cambistas suas operações nos templos, mas também nos mercados ou feiras, por serem lugares públicos, onde instalavam suas bancas nas quais expunham as moedas, para atrair seus clientes e realizar a troca das moedas estrangeiras pelas nacionais. Inspirando confiança ao público, por essas atividades desenvolvidas, esses cambistas passaram a receber moedas em depósito que lhes eram confiadas para posterior devolução e, deste modo, providos de capital, davam o mesmo em empréstimos aos que deles necessitavam.

Das bancas dos cambistas adveio o termo banco, até hoje utilizado para caracterizar o principal tipo de instituição financeira nos tempos modernos. ${ }^{9}$

Desse modo, na Idade Média, surgiram os primeiros estabelecimentos bancários, que realizaram papel relevante no atendimento aos comerciantes estrangeiros em operações de troca de moedas, e outras operações bancárias, notadamente as de empréstimos. Temse nessa época, na Itália, o Banco de Veneza, fundado em 1171, o primeiro surgido na Europa, que atuou durante seis (06) séculos, até o ano de 1.797.

A seguir, entre os mais importantes, surgiram em 1408, em Gênova, na Itália, a Casa di San Giorgio (ou Banco de São Jorge), que se constituiu na primeira sociedade anônima conhecida; em 1609, o Banco de Amsterdam, na Holanda, que foi levado à insolvência em 1820 , ou seja, 211 anos após a sua fundação; contemporaneamente, o Banco da Suécia; fundado em 1694, o Banco da Inglaterra, em 1800; o Banco de França, fundado por Napoleão. ${ }^{10}$

$\mathrm{Na}$ Idade Moderna, com o desenvolvimento das atividades comerciais e industriais, ocorrido após os dois grandes conflitos mundiais, gerou-se o crescimento do apelo ao crédito, não só na esfera privada como também na

8 MOLLE, Giacomo. I Contratti Bancari, ob. cit., p.5; NELSON ABRÃO. Direito Bancário, cit., $\mathrm{n}^{\mathrm{o}} 05, \mathrm{p} .13$.

9 MARTINS, Fran. Contratos e Obrigações Comerciais, cit., nº 372, p.408.

10 RODIÈRE, René e RIVES-LANGE, Jean-Louis. Droit Bancaire. p.18-20, Paris, 1980; ABRÃO, Nelson. Direito Bancário cit., $\mathrm{n}^{\circ}$ 6, p.14; MARTINS, Fran. Contratos e Obrigações comerciais cit., $\mathrm{n}^{\mathrm{0}} 372$, p.408-409. 
pública, fatos que fizeram com que se alterasse a própria estrutura e função dos Bancos, passando-se dos modelos antigo e intermédio, para o moderno, cujas atividades primordiais caracterizam-se por tomar os fundos monetários amealhados pelos poupadores e emprestá-los aos que do crédito necessitam, para o desenvolvimento dos respectivos negócios. E em razão desses fatos, multiplicou-se o número de Bancos, fundados, notadamente, na Europa, projetando-se com maior rapidez esse crescimento na transição do Século XIX para o XX, da nossa era.

No Brasil, o primeiro Banco, fundado ainda na fase colonial, em 12 de outubro de 1808, por Alvará de D. João VI, quando para cá transferiu a Corte portuguesa, foi o Banco do Brasil, que experimentou, inicialmente, transformações e episódios de liquidação, aprovadas por assembléia geral de 11.04.1835. Fundiu-se com o Banco Comercial em 31.08.1853 e com o Banco da República dos Estados Unidos do Brasil em 17.12.1892, conservando sempre a denominação de Banco do Brasil. Reorganizou-se definitivamente, tendo seus estatutos aprovados pela Lei $\mathrm{n}^{\mathrm{o}} 1.455$, de 30 de dezembro de 1905 , contando atualmente uma existência de dois séculos, ou seja, precisamente 200 anos, que ocorrerá na data próxima de 12 de outubro do ano vindouro de 2008.
Atualmente participam do comércio bancário pátrio extenso número de Bancos públicos e privados, que integram o grande mundo das instituições financeiras, estando os nacionais privados dependentes para funcionar de autorização do Banco Central do Brasil, enquanto os estrangeiros estão sujeitos a autorização governamental, mediante decreto do Poder Executivo, como dispõe o artigo 18, da Lei 4.595/64.

\section{CLASSIFICAÇÃO DOS BANCOS}

A pretensão de realizar a distinção dos Bancos, em classes, mediante critérios rígidos, a par de haver sido tentada historicamente pela doutrina, está em fase de desaparecimento, devido às dificuldades encontradas, como bem adverte renomado comercialista nacional, ao afirmar que "classificar os Bancos é entrar no campo arbitrário". ${ }^{11}$

Todavia, no âmbito do nosso direito interno, a Lei 4.595, de 31 de dezembro de 1964, chamada Lei da Reforma Bancária, classificou os Bancos pelo gênero instituições financeiras, dividindo-os em instituições financeiras públicas e privadas (art. 17). Entre as públicas, figuram os Bancos Públicos, criados e mantidos pelos Governos federal e estaduais, encarregados da execução das políticas creditícias

11 CARVALHO DE MENDONÇA, J.X. Tratado de Direito Comercial Brasileiro, cit., vol. 7, p.39. 
respectivas, retratando o intervencionismo estatal no setor.

Integram-se especificamente no setor público, o Banco Central do Brasil, instituição bancária cúpula do Sistema Financeiro Nacional, regulador e fiscalizador das demais instituições bancárias; o Banco do Brasil, sociedade de economia mista, órgão executor da política creditícia e financeira do Governo Federal (art. 19), referido acima; o Banco Nacional do Desenvolvimento Econômico e Social (BNDES), instrumento de execução da política de investimentos do Governo da União (art. 23); a Caixa Econômica Federal (CEF), empresa pública, criada inicialmente pelo Decreto $\mathrm{n}^{\mathrm{o}} 2.723$, de 12 de janeiro de 1861 , de D. Pedro II, ${ }^{12}$ que atualmente tem sua estrutura definida pelo Decreto-Lei $\mathrm{n}^{\circ} 759$, de 12.08.1969, alterado pelo Decreto-Lei $n^{\circ} 1.259$, de 19.02.1973, regendo-se pelo Estatuto aprovado pelo decreto $\mathrm{n}^{\mathrm{o}} 3.882$, de 08.08.2001. Extinto o Banco Nacional da Habitação (BNH), pelo Decreto-Lei no 2.291, de 21 de novembro de 1986, passou a CEF à execução do Sistema Financeiro da Habitação (SFH), como dispõe o artigo 24, parágrafo único, da Lei da Reforma Bancária.

Ainda no setor público, mas no âmbito estadual, existiam, até pouco tempo, as Caixas Econômicas Esta- duais, previstas no artigo 24, parágrafo único da Lei $\mathrm{n}^{\circ} 4.595 / 64$, todas atualmente extintas. Nos três Estados do Sul (Rio Grande do Sul, Santa Catarina e Paraná) e no Estado de Mato Grosso do Sul, existe o Banco Regional de Desenvolvimento do Extremo Sul (BRDE), que constitui Banco de fomento. No Rio Grande do Sul, foi criada no Governo anterior a Caixa-RS, também Banco de fomento.

Compartilham com as instituições financeiras públicas, na composição do Sistema Financeiro Nacional, as instituições financeiras privadas, reguladas também pela Lei 4.595/64, (art. 25 e seus $\S \S$ ), que têm marcada presença no mundo financeiro na figura do Banco Comercial, cujo desempenho é dos mais abrangentes, configurando-se em banco múltiplo ou universal, ou seja, aquele que pratica substancialmente quase todas as operações bancárias, como sucede na Alemanha. ${ }^{13}$

Os Bancos Comerciais encontramse atualmente regulamentados pela Resolução $n^{\circ} 469$, de 07.04.1978, do Banco Central, que os define como instituições financeiras privadas, constituídas sob a forma de sociedade anônima, tendo por objetivo precípuo proporcionar o suprimento oportuno e adequado dos recursos necessários para financiar, a curto e médio prazo, o

12 DE OLIVEIRA, Celso Marcelo. Manual de Direito Bancário, nº 29, p.201-202, Edição IOB Thomson, São Paulo, 2006.

13 ABRÃO, Nelson. Direito Bancário cit., nº 12, p.23. 
comércio, a indústria, as empresas prestadoras de serviços e as pessoas físicas, podendo realizar todas as operações pertinentes a esse tipo de instituição bancária, tais como, descontar títulos, realizar operações de abertura de crédito, captar depósitos, etc. ${ }^{14}$

Dentre outras instituições creditícias que se incluem no elenco das instituições financeiras privadas, figuram as Cooperativas de crédito, que são sociedades de pessoas com forma jurídica própria, de natureza civil, sem finalidade lucrativa, organizadas para a prestação de serviços ou para o exercício de outras atividades de interesse comum dos associados.

As Cooperativas de crédito estão regidas pela lei geral da categoria (Lei 5.764, de 16.12.1971), e em especial pela Lei da Reforma Bancária (artigo 55, da Lei 4.595/64), esta última no que concerne a autorização para funcionamento e fiscalização das mesmas, a cargo do Banco Central. As cooperativas de crédito têm por finalidade propiciar empréstimos aos seus associados, em valores limitados e mediante taxas módicas de juros, visando auxiliar de modo particular o pequeno trabalho dos mesmos em qualquer atividade que este labor se manifeste, seja no setor agrícola, industrial, comercial ou simplesmente profissional. ${ }^{15}$

\section{DAS OPERAÇÕES BANCÁRIAS E SUA CLASSIFICAÇÃO}

Visando obviar a realização de seu objeto, os Bancos desempenham, em relação aos seus clientes, uma extensa gama de relações negociais, que recebem a denominação técnica de operações bancárias. A expressão encontra-se desde muito consagrada no nosso direito positivo, pois o Código Comercial, em sua Parte Primeira, no artigo 119, hoje revogada, dispunha, ao definir a figura do banqueiro, que "São considerados banqueiros os comerciantes que têm por profissão habitual do seu comércio as operações chamadas de Banco". E o antigo Regulamento 737 , de 25 de novembro de 1850 , que regia o processo comercial e que foi revogado com o advento do Código de Processo Civil de 1939, enumerava as operações bancárias entre os atos de comércio por natureza, inserindo estas no complexo da atividade empresária, como sendo aquela economicamente organizada para a prestação de serviços.

É de lamentar que o vigente Código Civil de 2002, em seu artigo 966, postase com timidez em relação às operações bancárias anteriormente caracterizadas no revogado artigo 119 do Código de Comércio, pois ao definir a figura do empresário, acolhendo a concepção

14 MARTINS, Fran. Contratos e Obrigações Comerciais, cit., n 375.

15 ABRÃO, Nelson. Direito Bancário cit., no 15, p.35-36; MARTINS, Fran. Contratos e Obrigações Comerciais, cit., n 378, p.425-428. 
legislativa consagrada no Código Civil italiano de $1942^{16}$ se refere não pela espécie, mas pelo gênero dos atos realizados pelo empresário que os pratica "profissionalmente (como) atividade econômica organizada para a produção ou a circulação de bens ou de serviços", sendo sustentável o entendimento de que as operações bancárias encontram-se incluídas pelo legislador atual nesse contexto, porquanto são os Bancos considerados também entidades empresárias.

Assim, a posição atual dos comercialistas é no sentido de que devem ser entendidas por operações bancárias a coleta ao público de aportes financeiros e a intermediação ou aplicação desses recursos, sejam próprios ou de terceiros, no atendimento das necessidades de crédito de empresas e particulares. ${ }^{17}$

No que pertine à classificação das operações bancárias, têm os autores, de modo geral, levado em consideração, de um lado, a coleta de recursos financeiros perante o público poupador e, de outro, a aplicação destes, sejam próprios ou de terceiros, às pessoas físicas ou empresários que deles necessitem para o desenvolvimento dos seus negócios, de modo que as classificam em operações passivas e em operações ativas. ${ }^{18}$

Outros as dividem em operações típicas e atípicas. Na primeira categoria incluem-se as que se relacionam com as atividades creditícias exercidas pelo Banco, seja na coleta de recursos financeiros do público poupador, seja nos empréstimos aos que deles necessitam. Assim as operações típicas subdividem-se em passivas, nas quais o Banco assume a posição de devedor da obrigação e em ativas, em que o Banco assume a posição de credor. ${ }^{19}$

Todavia, entendem outros autores, ainda, entre os quais Giuseppe Ferri e Nelson Abrão, que o melhor critério classificatório das operações bancárias é o que leva em conta a importância do negócio praticado, ou seja, a atividade dos Bancos resulta de uma dúplice categoria de operações. Na primeira categoria figuram as operações essenciais ou fundamentais, que representam a função própria do Banco, qual seja o exercício do crédito em todas as suas modalidades. Estas consistem, de um lado, na coleta de capitais junto ao público poupador, caracterizando operações passivas, e, de outro lado, as

16 ABRÃO, Nelson. Direito Bancário, cit., nº 21, p.52-56.

17 Sobre o assunto, v. COELHO, Fábio Ulhoa. Manual de Direito Comercial, p.445, Ed. Saraiva, São Paulo, 2005.

18 Em tal sentido CARVALHO DE MENDONÇA, J.X. Tratado cit., p.145; MARTINS, Fran. Contratos e Obrigações Comerciais, cit., nº 383, p.432.

19 COELHO, Fábio Ulhoa. Manual de Direito Comercial, cit., p.447. 
que consistem na distribuição dos capitais, mediante a concessão de empréstimos aos que deles necessitam para o desenvolvimento dos seus negócios, caracterizando operações ativas. Existe ainda uma segunda categoria de operações bancárias por meio das quais o Banco presta serviços aos seus clientes, recebendo estas a qualificação de operações acessórias ou complementares.

Deste modo, segundo os autores anteriormente mencionados, o critério mais adequado para classificar as operações bancárias é o que as divide em operações principais essenciais ou fundamentais, podendo estas serem passivas ou ativas e em operações acessórias ou complementares, nas quais o Banco não concede, nem recebe crédito, mas apenas presta serviços aos seus clientes. ${ }^{20}$

Assim sendo, constituem operações principais, essenciais ou fundamentais, exemplificativamente, o depósito, o redesconto, a conta corrente, as aplicações financeiras dos clientes, etc., que são operações passivas e, por outro lado, também exemplificativamente, o empréstimo, o desconto, a abertura de crédito, a conta de cheque especial, etc., que são operações ativas; e, por fim, a custódia de valores, o serviço de cofres de segurança, a cobrança de títulos, etc., que formam as operações acessórias ou complementares.

\section{DOS PRINCÍPIOS E REGRAS ORDENADORES DOS CONTRATOS BANCÁRIOS}

Insertos no contexto geral das relações contratuais, os contratos bancários devem ser informados em sua estrutura, conteúdo e fins por uma principiologia comum a todos os contratos, civis e comerciais, dentre tais, notadamente, os princípios da autonomia da vontade, da obrigatoriedade, caracterizada historicamente no pacta sunt servanda, porém, cum grano salis, como a seguir se passará a observar. O princípio da autonomia da vontade, ou da autonomia privada, está fundado, como é sabido, no individualismo, que é produto de tendências já verificadas nos sistemas romano e canônico e no liberalismo econômico, manifestado, historicamente, pelo jusnaturalismo e, filosoficamente, na doutrina de KANT, cujo pensamento figura como precursor da idéia de estado liberal. ${ }^{21}$

A autonomia da vontade traduz, portanto, um poder de disposição diretamente ligado à concepção tradicional relativa ao direito de propriedade privada, nos meandros do sistema de mercado, promotor da livre circulação de bens, cujo principal instrumento é o negócio jurídico. Essa teoria proclama que o sujeito é livre para contratar, escolher com quem contratar e

20 FERRI, Giuseppe. Manuale de Diritto Commerciale, p.680, Turim, 1971; ABRÃO, Nelson. Direito Bancário, cit., nº 23, p.59-61.

21 Em tal sentido, é também a posição doutrinária de Francisco Amaral em Direito Civil Introdução, p.358, 5.ed. Renovar, Rio, 2003. 
estabelecer, sem limitações, o conteúdo do contrato e seus efeitos.

As conseqüências do reconhecimento da autonomia da vontade pela teoria clássica vêm desaguar nos princípios da liberdade contratual, da força obrigatória dos contratos e do efeito relativo, ${ }^{22}$ este último ainda estava concebido no artigo 928 da codificação civil revogada. Nos tempos atuais, todavia, esses três princípios encontramse balizados pela intervenção estatal no contrato, visando preservar o interesse público no contexto dessa relação jurídica e é aplicável também aos contratos bancários.

E é de notar-se que, significativamente, com o amadurecimento das idéias de solidariedade e de socialidade dos direitos, a Constituição Federal restou por adotar em seu artigo $5^{\circ}$, XXIII, de igual modo, o princípio da função social da propriedade, com o escopo de combater a especulação latifundiária.

A discussão legislativa acerca do Projeto da nova codificação civil, no Congresso Nacional, acolhendo as idéias da socialidade que, em conseqüência da regra Constitucional, passou a ser concebida pelos congressistas, na discussão do Projeto civilista, fez com que o princípio da função social do contrato fosse, de igual modo, contemplado na legislação civil comum, em sede de relação contratual, estabelecendo-a no artigo 421, da nova codificação.
Assim, diante dessa uniforme posição tomada pela legislação especial e também pela lei comum, a nova teoria contratual vem sofrendo significativas transformações nos últimos tempos, fruto de uma consciência social moldada sob novas idéias que visam tornar mais equânime e mais justa a relação contratual. Essa nova tomada de posição teve por escopo senão afastar, pelo menos, minorar ou relativizar os efeitos do individualismo e do patrimonialismo imperantes no passado, na esfera contratual.

Essas idéias de equanimidade e de justiça social a serem observadas no âmbito da contratação servem para limitar o tradicional princípio da autonomia da vontade, sempre que este estiver em confronto com o interesse social, que atende também os postulados da ordem pública.

Assim sendo, concebendo o legislador que a liberdade de contratar não pode divorciar-se da função social caracterizadora dessa relação jurídica, positivou a dita função no Código Civil de 2002, como regra geral a ser observada em todas as contratações na área do direito privado.

A par de acolher o princípio da função social no campo da teoria geral dos contratos, extensivo a toda a tipologia contratual indistintamente, $o$ legislador civil reconheceu também a atuação desse princípio especificamente nos contratos de adesão, ao estabelecer no artigo 423 da codificação a regra de

22 Sobre esse tema, v. ainda, Francisco Amaral, Direito Civil, Introdução, cit., p.359. 
que "Quando houver no contrato de adesão cláusulas ambíguas ou contraditórias, dever-se-á adotar a interpretação mais favorável ao aderente", repristinando, de certo modo, a regra vedatória das cláusulas abusivas, constantes no artigo 54 e $\S \S 1^{\circ}$ ao $4^{\circ}$, do Código de Defesa do Consumidor.

Ainda com o escopo declarado da adoção do princípio da função social do contrato, notadamente nos contratos de adesão, introduziu o legislador na codificação civil de 2002, o artigo 424, segundo o qual, "nos contratos de adesão, são nulas as cláusulas que estipularem a renúncia antecipada do aderente a direito resultante da natureza do negócio".

$\mathrm{Na}$ atualidade, a própria legislação civil, como se viu, ao adotar em sede de teoria geral dos contratos o princípio da função social, concebe-a como parte de uma realidade mais abrangente e como fator de alteração da realidade social, como o faz, de igual modo, com o direito de propriedade. $\mathrm{E}$ em face dessa concepção, consagra a rescisão do contrato lesivo (Cód. Civil, art. 157), anula o celebrado em estado de perigo (Cód. Civil, art. 156), sanciona o enriquecimento sem causa (Cód. Civil, art. 884-886); prescreve a resolução do contrato por onerosidade excessiva (Cód. Civil, art. 478-480); limita o valor da cláusula penal (Cód. Civil, art. 412413), etc., como salienta a doutrina. ${ }^{23}$
Deve-se ainda registrar que o Código de Defesa do Consumidor (CDC) acolhe extensivamente em seu texto a função social do contrato de consumo, estendendo-a também aos contratos bancários, pois ao definir os serviços, como categoria sujeita à disciplina dessa codificação especial, os inclui como atividade de consumo, e como tais "inclusive as de natureza bancária, financeira, de crédito...", praticadas pelo consumidor com os Bancos.

Assim sendo, diante da regra expressa contida no artigo $3^{\circ}, \S 2^{\circ}$, do $\mathrm{CDC}$, às relações de consumo praticadas com os Bancos é aplicável o princípio da função social do contrato. A aplicabilidade do CDC às operações bancárias encontra-se já sedimentada na jurisprudência, na Súmula 297 do S.T.J.

Quanto à sua estrutura e elementos constitutivos, encontram-se os contratos bancários regulados pelas regras da lei civil comum e quanto ao seu conteúdo e finalidades pela regência geral das regras de direito mercantil e, particularmente por disposições de direito bancário, salvo alguns contratos inominados que recebem a disciplina de leis especiais.

Não se deve esquecer de salientar que desde tempos transatos vem persistindo a unidade normativa, civil e comercial, para a regência das obrigações desses dois setores da relação jurídica privada.

Mas, a par da confluência dessas duas áreas jurídicas, quanto ao direito

23 Entre outros, Caio Mário da Silva Pereira, Instituições de Direito Civil, vol. III, nº 185 , p.10-14, 11.ed., Forense, Rio, 2004. 
obrigacional, não se pode conceber que, com a revogação dos artigos $1^{\circ}$ a 456 , constantes da parte primeira do Código Mercantil de 1850, tenha-se transladada para o Livro II da codificação civil vigente, sob o título de Direito de Empresa, toda a normatividade de natureza mercantil sob a regência daquelas disposições revogadas. De outro modo, constituiria concepção deveras incorreta imaginar-se que parte do direito mercantil se tenha transmutado em civil, pelo simples fato de sua colocação tópico em sede civil.

Já no passado, a respeito das obrigações e contratos mercantis e nesse elenco incluídos os contratos bancários, havia regra expressa no artigo 121, do Código Comercial, segundo a qual "As regras e disposições do direito civil para os contratos em geral são aplicáveis aos contratos comerciais, com as modificações e restrições estabelecidas neste Código".

$\mathrm{Na}$ verdade, os contratos mercantis em geral e, no particular, os contratos bancários, socorrem-se das regras contidas na lei civil comum, quanto aos seus elementos pertinentes à capacidade, legitimidade das partes e à forma, mas regem-se pela lei mercantil, quanto à espécie, qualidade e demais características do objeto e a sua finalidade, porquanto a definição e disciplina destes últimos elementos não é própria da lei civil.

Quanto à forma, a disciplina é exclusiva da lei civil e a imensa maioria dos contratos mercantis e bancários obedece a forma não defesa em lei, segundo dispõe os artigos 104, III e 107 caput, do Código Civil, ou seja, a forma livre, devendo-se salientar que os contratos que envolvem compra e venda de imóveis, cujo valor não exceda a 30 salários mínimos vigentes no País, podem ser formatizados por escritura particular, segundo o artigo 108 da codificação civil. Todavia, por expressa disposição legal, podem ser realizados por escritura particular os contratos bancários que têm por objeto o financiamento de imóveis com garantia hipotecária, pertinentes ao Sistema Financeiro da Habitação (SFH), segundo o artigo 61, § 5 , da Lei 4.380/ 64, que criou o Banco Nacional da Habitação (BNH) e criou também o mencionado sistema de financiamento da casa própria.

Não obstante a lei civil autorizar a prática da forma livre para instrumentar a realização dos contratos bancários, estes são, na verdade, praticados mediante a utilização da forma escrita, podendo esta ser obtida com o auxílio da máquina, notadamente por meio da informática, que na atualidade é utilizada inclusive para instrumentar os negócios jurídicos mais solenes, como é o caso do testamento, em sede do direito das sucessões, segundo disposições do artigo 1.864 e outros, da codificação civil em vigor.

Conforme registra certa doutrina, "Não há mais no direito brasileiro contratos mercantis solenes", continuando o autor a afirmar que "a exigência da forma escrita para a plena eficácia das obrigações contratadas não 
se confunde com o requisito da solenidade para a constituição do contrato" (como acentua Fábio Ulhoa Coelho. ${ }^{24}$

\section{DAS OPERAÇÕES DOS BANCOS EM GERAL E DOS CONTRATOS QUE AS FORMALIZAM}

Como já foi explanado acima, as operações bancárias classificam-se, por sua natureza, em operações principais, essenciais ou fundamentais do comércio bancário, sendo estas subdivididas em operações ativas, nas quais o Banco figura como credor, e em operações passivas, em que o Banco assume a posição de obrigado ou devedor. De outro lado, o mesmo critério classificatório reconhece outra categoria de operações bancárias chamadas operações acessórias ou complementares, nas quais o Banco não concede empréstimos, nem recebe recursos financeiros dos poupadores em geral, mas tão somente assume o encargo de prestar serviços aos seus clientes.

\section{DAS OPERAÇÕES ATIVAS DOS BANCOS}

No elenco das operações principais, essenciais ou fundamentais do comércio bancário, que figuram como operações ativas, passam a ser examinadas, exemplificativamente, a de mútuo, a de desconto de títulos de crédito, a de cheque especial, a de empréstimo rural, a de empréstimo industrial, a de empréstimo em consignação, a de cartão de crédito, a de empréstimo mediante penhor de jóias, metais e pedras preciosas, dentre outras da mesma espécie, todas elas formalizadas por instrumentos de contrato que são nominados com a mesma denominação própria de cada uma.

\section{DO CONTRATO DE MÚTUO}

É o instrumento formalizador da operação de mútuo, a mais comum e mais ocorrente entre os contratos bancários. Representa também a espécie contratual mais antiga, realizada em todos os tempos pelos Bancos, havendo notícias de sua prática já no distante império babilônico, onde se encontrava regida pelo Código de Hamurábi, de aproximadamente 2.600 a.C., contendo regras restritivas da usura acerca da taxa de juros, segundo às quais, se o emprestador estabelecesse taxas de juros superiores a $20 \%$, não só perdia o direito à renda do capital emprestado, mas também ao próprio capital.

Para os romanos, foi o mútuo difundido entre os argenti e seus clientes, os quais exerciam atividades semelhantes aos atuais banqueiros, realizando operações de empréstimos mediante a cobrança de juros, devendo-se

24 Sobre esse requisito dos contratos mercantis, v. Fábio Ulhoa Coelho, Manual de Direito Comercial, p.445, Saraiva, São Paulo, 2005. 
ressaltar que na Idade Média essa cobrança de juros sobre os empréstimos recebeu a reprovação da Igreja Católica, que a considerou usurária, imoral e pecaminosa.

Com efeito, abandonando-se o vácuo temporal transcorrido entre o medievo e a época moderna, há que se registrar que o contrato de mútuo ingressou no direito brasileiro pelo artigo 247 do Código Comercial de 1850 , encontrando-se atualmente definido no artigo 586 e ainda explicitado, quanto a cobrança de juros, no artigo 591, ambos da codificação civil de 2002.

Segundo a doutrina especializada, esta relação contratual deve ser entendida como a operação bancária realizada entre o Banco e seu cliente, mediante a qual a instituição bancária coloca à disposição daquele determinada soma em dinheiro, em moeda corrente, para ser restituída ao mutuante na mesma espécie, qualidade e quantidade, dentro de certo tempo, com acréscimo de juros remuneratórios. ${ }^{25}$

O mútuo é espécie do gênero operações financeiras, que tem destacada predominância no campo das operações essenciais ou fundamentais e ativas dos Bancos. E no sentido específico, o contrato de mútuo deve ser considerado "o núcleo central do sistema creditório ou o centro de gravitação do comércio bancário segundo a expressão da doutrina especializada". ${ }^{26}$
O contrato de mútuo pode ser ajustado pura e simplesmente, amparado apenas no conceito pessoal e cadastral do tomador, ou mediante garantia fidejussória (aval, fiança) ou com garantia real (caução, penhor, hipoteca), tendo em vista que o direito creditório do credor repousa no patrimônio de devedor, segundo dispõem os artigos 391, do Código Civil e 591, do CPC. Todavia, deve ser registrado que o avalista de título de crédito vinculado a contrato de mútuo também responde pelas obrigações pactuadas, quando no contrato figurar como devedor solidário, conforme dispõe a Súmula $n^{\circ} 26$, do S.T.J.

Quanto aos juros remuneratórios a serem ajustados no contrato de mútuo, deve ser observada a taxa média de mercado estipulada pelo Banco Central, limitada ao percentual contratado, segundo dispõe a Súmula 596, do S.T.F. e a Súmula 296, do S.T.J., salientado que a taxa de juros de $12 \%$ ao ano, fixada no $\S 3^{\circ}$, artigo 192 , do texto original da Constituição Federal, foi revogada pela Emenda Constitucional $n^{\circ} 40$, de 29.05.2003 e bem assim está afastada a Lei da Usura (Decreto $22.626 / 33$ ), que fixava os juros remuneratórios no mesmo patamar de $12 \%$ ao ano (artigo $1^{\circ}$ ) e os juros moratórios em $6 \%$ a.a. (artigo $3^{\circ}$ ).

Finalmente, há que ser observado que os empréstimos desta espécie,

25 MARTINS, Fran. Contratos e Obrigações Comerciais, cit., nº 389, p.436; ABRÃO, Nelson. Direito Bancário, cit. no 32, p.94.

26 ABRÃO, Nelson. Direito Bancário, cit., nº 32, p.94. 
quando concedidos pelos Bancos a pessoa física ou jurídica que se dedique à atividade comercial ou à de prestação de serviços, poderão ser operados por meio de cédula de crédito comercial ou de nota de crédito comercial, seguindose as disposições da Lei 6.840, de 03.11.1980, bem como as que disciplinam a cédula de crédito industrial, contida no Decreto-Lei n ${ }^{\circ}$ 413, de 09.01.1969.

\section{DO CONTRATO DE DESCONTO}

O desconto de títulos de crédito é outra operação bancária tipicamente ativa, mediante a qual o Banco, nesse tipo de negócio jurídico, chamado descontário, antecipa ao cliente, chamado descontante, um adiantamento pecuniário, em troca de títulos de crédito sacados por este último contra terceiros, os quais são endossados ao Banco. Este endosso caracteriza-se como endosso translativo da posse-propriedade do título, segundo doutrina de tomo. ${ }^{27}$

Naturalmente, a quantia antecipada pelo Banco ao cliente descontante limita-se ao valor líquido dos títulos descontados, deduzidos os juros remuneratórios incidentes sobre a operação, calculados até o vencimento e a comissão de cobrança dos mesmos.

São objeto de desconto bancário, em regra, todos os títulos cambiais com vencimento futuro, tais como os não causais (letras de câmbio, notas promissórias) e bem assim os causais ou cambiariformes, representados pelas duplicatas de fatura, que constituem efetivos efeitos comerciais. Tanto no desconto dos títulos não causais, como nos cambiariformes, estes resultantes da compra e venda de mercadorias ou da prestação de serviços entre o comerciante, cliente do Banco e um terceiro, a instituição financeira descontária adquire a propriedade dos títulos, mediante endosso translativo, sob a figura da cessão de crédito, subrogandose no direito de crédito do cliente.

Destarte, pelos seus elementos constitutivos, o desconto bancário configura uma relação jurídica trilateral, composta pelo cliente, sacador ou emitente dos títulos descontados, que os aliena ao Banco descontário; por este que, mediante o endosso, adquire a propriedade dos títulos; e pelo sacado, que é o obrigado a implementar o pagamento dos títulos, nos respectivos vencimentos, salientando-se que, não resgatados estes, remanesce a coobrigação do descontante de reembolsar o Banco pela quantia que recebeu antecipadamente.

Por derradeiro, cabe observar que, adquirida pelo Banco a propriedade dos títulos descontados, pela figura da cessão de crédito; compete-lhe, obviamente, proceder a cobrança dos mesmos e bem assim o respectivo aceite, se for o caso.

27 Ver Pontes de Miranda, Tratado de Direito Privado, Tomo 36, § 4.050, nº 3, p.222-223, Edição Borsoi, Rio de Janeiro, 1971. 


\section{DO CONTRATO DE CHEQUE ESPECIAL}

Deve-se entender por contrato de cheque especial, que também é denominado contrato de cheques garantidos, a operação bancária ativa, mediante a qual o Banco concede a clientes selecionados a abertura de um crédito com limite e prazo determinados, para ser por estes utilizado por meio de cheques de categoria especial, fornecidos pela instituição creditadora. O Banco que concede o crédito é ordinariamente denominado creditador, enquanto o favorecido do empréstimo é chamado creditado.

Essa modalidade de crédito, cuja denominação se confunde com o instrumento de sua utilização, vem sendo genericamente identificada por "cheque especial". No entanto, pode adquirir denominações diversas, segundo a preferência do Banco instituidor do crédito. Haja visto, exemplificativamente, que no Banco do Brasil recebe a denominação específica de "cheque ouro", enquanto em outras instituições bancárias a de "cheque conterrâneo", no Banco do Nordeste do Brasil e a de "cheque BEC", no Banco do Estado do Ceará, segundo noticia a doutrina comercial. ${ }^{28}$

O cliente ou creditado, em benefício do qual é realizada a abertura de crédito, é indentificado, para a utilização do mesmo, através de um cartão fornecido pelo Banco, no qual constam o nome e a assinatura do beneficiário, o prazo de utilização do crédito, a indicação do estabelecimento creditador e bem assim o número da conta corrente do cliente ou creditado.

O deferimento do crédito pode ser puramente pessoal, segundo o teor de credibilidade que o creditado gozar perante o Banco creditador, aferida esta mediante avaliação criteriosa dos respectivos registros cadastrais, ou, ainda, com base no saldo médio que se verificar, por certo período, em sua conta corrente. Com efeito, essa aferição não érecomendada pelo Banco Central, segundo registra autor da área comercialista. ${ }^{29}$

A operação de cheque especial pode ser periodicamente renovada. Quanto aos juros remuneratórios ajustados contratualmente, incidentes sobre as parcelas utilizadas pelo creditado, são contados e debitados mensalmente na conta corrente do mesmo, ou na oportunidade da extinção do contrato, que poderá ser cancelado pelo Banco, no caso de descumprimento, pelo devedor, das obrigações contratuais, ou por opção deste ou, ainda, por desnecessidade de continuar a utilizar-se do crédito.

\section{DOS CONTRATOS DE EMPRÉSTIMO RURAL}

Tendo em mira os interesses que o agronegócio vem despertando no espírito das pessoas ligadas ao meio rural, o qual se expande com rara velocidade e dinamismo nos tempos modernos, agricultores e pecuaristas vêm dirigindo

28 MARTINS, Fran. Contratos e Obrigações Comerciais, cit., nº 401, p.443-445.

29 MARTINS, Fran. Contratos e Obrigações Comerciais, cit., nº 402, p.404. 
suas atenções para esses dois setores da vida rural. E, diante da escassez de aportes financeiros próprios, para enfrentá-los com os recursos técnicos necessários à obtenção de resultados, recorrem esses ruralistas aos Bancos para, mediante a consecução de empréstimos especializados e destinados a esses setores da atividade rural, conseguir os recursos necessários para enfrentar e desenvolver tais empreendimentos.

Os empréstimos rurais, obedecidos os ditames traçados pela política governamental, visando o desenvolvimento técnico, metódico e dinâmico da produção primária, dispõe de estrutura organizada para atender as necessidades financeiras de cada um dos dois setores produtivos, de modo que os empréstimos a eles destinados estão divididos em agrícolas e pecuários.

Os contratos de empréstimo agrícola obedecem a limites de crédito fixados segundo o tipo de cultura a ser desenvolvida pelo agricultor, isto é, existem parâmetros limitativos para a cultura de lavouras de arroz irrigadas e não irrigadas, de soja, de trigo, de milho, de girassol, etc., mediante juros remuneratórios do capital empestado reduzidos, sendo os prazos dos financiamentos compatíveis com o período vegetativo de cada espécie de cultura, devendo-se salientar que, por disposição legal expressa, o prazo do penhor agrícola não excederá de 3 (três) anos, prorrogável por mais 3 (três),segundo o artigo 61, do Decreto-lei n ${ }^{\circ} 167$, de 14 de fevereiro de 1967, observado, no entanto, o prazo compatível ou necessário para cumprir o período vegetativo do tipo de cultura que for praticado. Pode haver pacto de capitalização de juros nos contratos de empréstimo rural, segundo dispõe a Súmula 93, do S.T.J.

As garantias do contrato de empréstimo agrícola, que constituem espécie de penhor rural, admitidas pela cédula rural pignoratícia, esta criada inicialmente pela tradicional Lei $\mathrm{n}^{\circ} 492$, de 30 de agosto de 1937, que criou também o penhor agrícola (arts. $6^{\circ}$ ao $\left.9^{\circ}\right)$ e o penhor pecuário (art. 10 a 13), ${ }^{30}$ devem constar no instrumento escrito do respectivo contrato, segundo dispõe o artigo 14 , inciso $\mathrm{V}$, do diploma legal referido, devendo serem integradas pelo fruto pendente a ser produzido pelo tipo de cultura praticado pelo agricultor e bem assim pelas máquinas e utensílios agrícolas empregados no empreendimento e ainda, por outros bens necessários para completar o complexo garantidor do empréstimo.

No que diz com os empréstimos da espécie, concedidos a pequenos e a micro-produtores rurais, são estes subvencionados pelo Programa Nacional de Fortalecimento da Agricultura Familiar (PRONAF), com recursos do Tesouro Nacional, com o objetivo de incrementar as culturas agrícolas a que os referidos beneficiários estão habituados a praticar, sendo portadores de conhecimentos práticos e experiência, para o exercício do mister. 
Essa modalidade de empréstimo agrícola, que deve observar a estrutura formal da Nota de Crédito Rural, estatuída pelo Decreto-lei 167/67, em seus artigos 27 e 28 , dispensada a garantia real exigida para os empréstimos de maior porte, requer que o seu instrumento formal seja levado a registro no Ofício de Imóveis, com o objetivo de conferir-lhe eficácia em relação a terceiros e, conseqüentemente, a obtenção do efeito erga omnes. ${ }^{31}$

Esse título de crédito deve estar revestido dos requisitos exigidos pelas disposições legais que regulam esta modalidade de empréstimo, cujo prazo não excederá a 2 (dois) anos, mas dito prazo deverá guardar compatibilidade com o período vegetativo do tipo de cultura a ser praticado pelo agricultor.

Por fim, extinto o prazo do empréstimo e não prorrogado este na forma permitida na lei, deve o mutuário repôlo ao Banco financiador, pelo modo estipulado na avença, que poderá ser parcelado ou integral.

Os contratos de empréstimo pecuário, embora dirigidos para tipo de empreendimento diverso do que se destina ao empréstimo agrícola e não obstante se incluam no mesmo gênero dos empréstimos rurais, obedecem, de igual modo, a limites fixados em conformidade com o tipo de atividade pecuária empreendida pelo pecuarista postulante do empréstimo, ou seja, existem parâmetros fixadores dos limites para o financiamento à exploração de gado bovino, ovino, suíno, etc., e bem assim quanto aos juros remuneratórios do capital emprestado, prazo de vigência da avença; regras técnicas pertinentes à manutenção da saúde do rebanho; e outras necessárias ao sucesso do empreendimento. E, no que diz respeito ao primeiro tipo de exploração pecuária, isto é, a de gado bovino, há que se realizar, ainda, a distinção quanto ao objeto do empréstimo, isto é, se destinado à criação, reprodução do rebanho ou destinado à engorda. Pode haver pacto de capitalização de juros nos contratos de empréstimo rural em geral, dos quais participa o empréstimo pecuário, segundo a Súmula 93 do S.T.J.

As garantias do contrato de empréstimo pecuário são as que constituem o objeto do penhor pecuário, cujas disposições reguladoras desse tipo de garantia encontram-se atualmente na nossa codificação civil de 2002 (artigos 1.444 a 1.446), salvo quanto ao prazo do ajuste, que encontra comando legal expresso no Decreto-lei $n^{\circ} 167 / 67$, segundo o qual não é admitido para o penhor pecuário prazo superior a 5 (cinco) anos, podendo ser prorrogado por mais 3 (três) anos.

\section{DO CONTRATO DE EMPRÉSTIMO INDUSTRIAL}

Para suprir as necessidades financeiras acaso enfrentadas no desenvolvimento dos seus negócios, as pessoas físicas ou jurídicas dedicadas à ativi-

31 ABRÃO, Nelson. Direito Bancário, cit., nº 138, p.284-285. 
dade industrial podem valer-se do empréstimo bancário destinado a atender financeiramente esse ramo de trabalho empresarial, o qual é operado por meio da cédula de crédito industrial ou da nota de crédito industrial, que constituem títulos de crédito de rápida e fácil operacionalidade, utilizáveis segundo a hipótese concreta que se apresentar.

Essa modalidade de empréstimo bancário foi inicialmente adotada com o advento do Decreto-lei $\mathrm{n}^{\circ} 1.271$, de 16 de janeiro de 1939 , tendo prosseguimento com os diplomas que a este sucederam, e encontrando-se atualmente sob a regência do Decreto-lei $n^{\circ} 413$, de 09 de janeiro de 1969.

A cédula de crédito industrial representa título certo e líquido, cujo valor é o do empréstimo concedido pelo Banco ao cliente, sendo tal importe creditado pelo Banco, em conta vinculada à operação, a ser utilizada pelo creditado por meio de cheques, saques, recibos, ordens, cartas ou quaisquer outros documentos, na forma estipulada no instrumento cedular ou no orçamento que a este é anexado (arts. $4^{\circ}$ e 10). As importâncias fornecidas pelo Banco vencem juros remuneratórios segundo os índices fixados pelo Conselho Monetário Nacional, bem como correção monetária e taxas, incidentes sobre os saldos devedores da conta vinculada à operação, exigíveis no final de cada semestre civil e também em outras datas, fixadas no título (art. $5^{\circ}$ ). A taxa de juros remuneratórios está sujeita à capitalização, segundo dispõe a própria lei (art. 14, VI), sendo assim entendida pela jurisprudência consolidada, constante da Súmula 93, do S.T.J.

O mencionado título de crédito encerra em seu conteúdo promessa de pagamento em dinheiro, que se encontra assegurado por garantia real, cedularmente constituída (art. $9^{\circ}$ ) em cláusula própria, na qual devem constar a descrição pormenorizada dos bens que constituem objeto do penhor, tais como a espécie, a qualidade, a quantidade, as marcas (se houver), bem como a indicação, situação, confrontações do imóvel em que se encontram depositados os bens penhorados e também o registro imobiliário do mencionado instrumento (art. 14, V), do referido diploma legal.

Além do penhor cedular (arts. $9^{\circ} \mathrm{e}$ 14), a cédula de crédito industrial admite outras modalidades de garantia, tais como a alienação fiduciária e a hipoteca cedular (art. 19). Esse penhor deve ser constituído pelas máquinas e aparelhos utilizados na indústria, matérias-primas, animais destinados à industrialização de carnes, sal, veículos automotores, dragas, letras de câmbio, promissórias, duplicatas, e outros (art. 20). Constituem, ainda, objeto da hipoteca cedular, as construções (pavilhões da fábrica ou do complexo industrial), o terreno em que se apóia o complexo, as instalações e benfeitorias (art. 24). Constituem objeto da alienação fiduciária, os bens indicados no Decreto-lei 911/69 e na Lei $4.728 / 65$, esta chamada Lei do Mercado de Capitais.

Em casos especiais, o empréstimo industrial poderá ser operacionalizado por meio de nota de crédito industrial, 
que consubstancia, como ocorre também com a cédula de crédito industrial, promessa de pagamento em dinheiro, constituída sem garantia real (art. 14). Os requisitos para a sua constituição encontram-se indicados no artigo 16 do Decreto-lei no $413 / 69$.

Goza o respectivo crédito de privilégio especial. Quanto ao mais, exceto a ausência de garantia e a inscrição imobiliária, à nota de crédito industrial aplicam-se as disposições legais pertinentes à cédula de crédito industrial (art. 18).

\section{DO CONTRATO DE CARTÃO DE CRÉDITO}

O contrato de cartão de crédito é a modalidade contratual moderna que tem por escopo suprir as carências financeiras pontuais de uma grande faixa da população, normalmente assalariada, que não dispõe de soma de dinheiro bastante para a aquisição de bens e de serviços, durante alguns dias do mês corrente.

A instituição do cartão de crédito, na sua feição atual, surgiu nos Estados Unidos, na década de 50 do século anterior, originalmente com as modalidades implantadas pelo Diners Club e pelo American Express, que permitiam a aquisição a prazo de bens e serviços no setor de hotelaria, turismo e transportes, sendo que no final dessa década o negócio passou a interessar aos Bancos que o adotaram com celeridade e dinamismo. Da América, o uso do cartão de crédito emigrou para a Europa e daí disseminou-se pelo mundo inteiro. ${ }^{32}$

No Brasil, foi o cartão de crédito introduzido na década de 60 do século anterior, propiciando atualmente a aquisição de uma numerosa gama de bens e serviços a curto e médio prazos, além de oferecer o saque, pelo cliente, de fundos por ele disponíveis no Banco emissor do cartão.

Deve-se entender por contrato de cartão de crédito o documento de natureza negocial destinado à aquisição de bens e serviços a curto e médio prazo, cujo titular goza de um limite de crédito perante uma instituição financeira, que o credencia também a efetuar saques de dinheiro em caixas eletrônicas do Banco emissor do cartão. ${ }^{33}$

O cartão de crédito representa um negócio jurídico atípico e complexo, do qual participam três pessoas intervenientes, tais como o emissor, o titular do cartão ou aderente e o fornecedor. O emissor é geralmente um Banco, que realiza a intermediação do negócio entre o titular do cartão e o fornecedor dos bens e serviços; enquanto o titular é o beneficiário, autorizado pelo Banco emissor a utilizar o cartão para as aquisições mencionadas; e, finalmente, a figura do fornecedor, ou seja, o terceiro integrante do negócio jurídico, que vende os bens ou presta os serviços adquiridos pelo titular do cartão. 
Há que se salientar que a relação jurídica de cartão de crédito biparte-se em dois vínculos distintos. O primeiro se estabelece pelo chamado contrato de filiação, em razão do qual o emissor se obriga a pagar ao fornecedor a quantia ou o preço da compra dos bens ou da realização dos serviços adquiridos pelo titular do cartão, antes mesmo de receber deste a mencionada quantia ou preço, donde passar o emissor do cartão (Banco) a ser o devedor responsável perante o fornecedor para pagar o valor das operações realizadas pelo cartão de crédito. $\mathrm{O}$ segundo vínculo é o que se estabelece entre o titular do cartão de crédito e o emissor do mesmo, pelo qual aquele se obriga a pagar diretamente a este o valor-preço dos bens adquiridos e dos serviços recebidos do fornecedor.

Por outro lado, o vínculo que se estabelece entre o adquirente dos bens ou serviços e o fornecedor dos mesmos é indiferente ao contrato de cartão de crédito, pois decorre exclusivamente de negócio jurídico de compra e venda, tornando-se irrelevante seja o mesmo realizado por meio de cartão de crédito ou por qualquer outra modalidade de negócio. Destarte, embora a operação de cartão de crédito possa sugerir uma relação jurídica triangular, na verdade ela é apenas bilateral, porque o terceiro vínculo acima referido, emergente da compra e venda, se estabelece entre comprador e vendedor, podendo aquele exercer contra este as ações e execuções que resultarem de deficiências pertinentes aos bens ou serviços adquiridos, mas não em razão do negócio haver sido realizado por meio de cartão de crédito. Não integra, pois, a compra e venda, em sua essência, a relação jurídica de cartão de crédito. ${ }^{34}$

A emissão de cartão de crédito é solicitada pelo cliente ao Banco com o qual mantém relações negociais, e este o confecciona em forma impressa, com a identificação do titular, número e prazo de vigência. E com a entrega do cartão ao cliente, pelo Banco, o mesmo aceita as cláusulas contratuais preestabelecidas pelo emissor, configurando, desse modo, a avença, contrato de adesão, que se submete às regras do Código de Defesa do Consumidor (CDC), pois já se manifestou a jurisprudência, atualmente consolidada, que a administradora de cartão de crédito configura instituição financeira, como dispõe a Súmula 283, do S.T.J. e, como tal, está submetida às regras especiais do CDC, como dispõe a Súmula 297, do mesmo Tribunal Superior. ${ }^{35}$

Deve ser observado, por oportuno, que a emissão de cartão de crédito pelo Banco ao seu cliente, resulta da credibilidade pessoal ou patrimonial que este goza perante aquele. A par disso, a insegurança e o cometimento de atos ilícitos nos grandes centros urbanos têm levado os Bancos a exigir a contratação, pelo titular do cartão, de um seguro de

34 MARTINS, Fran. Contratos e Obrigações Comerciais, cit., nº 459, p.509-511; ABRÃO, Nelson. Direito Bancário, cit., nº 82, p.190-192.

35 ABRÃO, Nelson. Direito Bancário, cit., n 82, p. 188. 
crédito, cujo prêmio é pago mensalmente por este, visando prevenir os efeitos de furto ou roubo do cartão.

O contrato de cartão de crédito é ajustado com prazo determinado, de modo que a ocorrência desse evento torna-o extinto. Pode extinguir-se também a avença antecipadamente por opção unilateral do cliente, ou ainda, por iniciativa do Banco emissor, toda vez que o beneficiado deixar de gozar da confiança daquele, resultante do uso indevido do cartão ou por descumprimento das obrigações contratuais. ${ }^{36}$

\section{DO EMPRÉSTIMO MEDIANTE PENHOR DE JÓIAS, METAIS E PEDRAS PRECIOSAS}

Esta modalidade de empréstimo tem existência longínqua, pois foi inaugurada com a criação da Caixa Econômica Federal, inicialmente denominada Monte de Socorro, pelo Governo Imperial, com o Decreto $\mathrm{n}^{\mathrm{o}} 2.273$, de 12 de janeiro de 1861, promulgado por Dom Pedro II, mantendo-se até agora como modalidade de empréstimo realizado pela Caixa, com exclusividade.

Para as Agências desta instituição bancária que operam neste Estado, o empréstimo vem sendo garantido exclusivamente por penhor de jóias, ao passo que em Agências sediadas em outros Estados, o penhor é estendido a outros metais e pedras preciosas, constituindo esse tipo de penhor, que tem a natureza de penhor comum, a única garantia que assegura à entidade financiadora a reposição do capital emprestado.

Trata-se de empréstimo de pequeno valor, cujos limites partem da quantia mínima de $\mathrm{R} \$ 50,00$, podendo chegar ao patamar máximo de $\mathrm{R} \$ 50.000,00$, por cliente, situando-se o limite médio bem abaixo deste limite máximo, variando os prazos entre $30,60,90,120$, 150 e 180 dias, permitido ao cliente renova-los ao término de cada um.

Esses limites do empréstimo são fixados em percentuais aferidos sobre o valor de avaliação dos bens pelo cliente oferecidos em garantia, os quais são avaliados por técnico da instituição emprestadora, levadas em conta, também, a qualificação e a categoria dos objetos que constituem a garantia. Assim sendo, o valor do empréstimo deve corresponder à percentagem que se situa entre dez e oitenta por cento do valor da avaliação.

Os juros remuneratórios, incidentes sobre as operações da espécie, são variáveis, segundo o limite maior ou menor do empréstimo, situando-se os mesmos entre as taxas de $1,80 \%$ a $2,85 \%$ fixadas na contratação inicial e conservadas no mesmo patamar, na eventualidade renovação do empréstimo ao final do prazo ajustado entre as partes.

Liquidado o empréstimo, integral ou parcialmente, são os objetos constitutivos da garantia desonerados e devolvidos ao financiado, na proporção dos recolhimentos realizados por este a título de pagamento parcial ou total.

36 ABRÃO, Nelson. Direito Brasileiro, cit., nº 84, p. 194. 


\section{DAS OPERAÇÕES PASSIVAS DOS BANCOS}

Classificadas igualmente como operações principais, essenciais ou fundamentais dos Bancos, porque integrantes também, por sua natureza, da prática habitual e própria do comércio bancário, são as operações passivas, mediante as quais a instituição bancária capta recursos financeiros do público poupador, para emprestar aos que necessitam do crédito para desenvolver seus negócios, ou negocia seus ativos com outras instituições para suprir necessidades de caixa, ou ainda, recebe capitais de seus clientes para reaplicação no mercado de capitais, assumindo o Banco em todos esses casos, o papel de obrigado ou devedor.

Nesse elenco, figuram exemplificativamente, dentre outras, a operação de conta corrente credora, a de redesconto de títulos, a de aplicação financeira ou de fundos de investimento, a de caderneta de poupança, etc., como os principais negócios dessa espécie, todas elas formalizadas por instrumentos de contrato, nominados com a mesma designação própria de cada uma. Assim, o contrato de conta corrente credora, o contrato de redesconto de títulos, o contrato de aplicação financeira ou de investimento, o contrato de caderneta de poupança, etc.

\section{DO CONTRATO DE CONTA CORRENTE CREDORA}

O contrato de conta corrente credora apresenta-se na prática bancária como o instrumento formalizador do negócio jurídico intitulado conta corrente credora, que se inclui entre as principais operações passivas dos Bancos. Esta tem provocado as mais variadas caracterizações pela doutrina e pela legislação, a começar com a introduzida pelo Código italiano, em seu artigo 1.834 , ao referir que "Nos depósitos de uma soma de dinheiro em um Banco, este lhe adquire a propriedade e é obrigado a restituí-la na mesma espécie monetária, no vencimento do prazo convencionado, ou à solicitação do depositante, com observância do período de pré-aviso estabelecido pelas partes ou pelo uso" ${ }^{37} \mathrm{E}$, segundo a doutrina francesa, "Para os juristas, o depósito de fundos em um banco é o contrato pelo qual uma pessoa entrega certa soma de dinheiro a seu banqueiro, que se obriga a lhe restituir, a seu pedido, nas condições previstas". ${ }^{38}$

Em palavras mais simples, definem autores nacionais, essa operação passiva dos Bancos, referindo que se pode “entender por depósito pecuniário, ou simplesmente depósito, a operação bancária segundo a qual uma pessoa entrega ao banco determinada impor-

37 É a disposição do Código Italiano revelada por Nelson Abrão, Direito Bancário, cit., $\mathrm{n}^{\mathrm{o}} 39, \mathrm{p} .108$.

38 RODIÊRE, René e RIVES -LANGE, Jean-Louis. Droit Bancaire, cit., p.183, Paris, 1980. 
tância em dinheiro, ficando o mesmo com a obrigação de devolvê-la no prazo e nas condições convencionadas". ${ }^{39}$ Denomina-se depositante ou correntista a pessoa interveniente no contrato que efetua o depósito em dinheiro e depositário o Banco que recebe o depósito e do primeiro torna-se devedor.

Sobre o saldo credor apresentado mensalmente pela conta corrente, no passado conta gráfica escriturada em forma contábil, os Bancos abonavam juros compensatórios aos depositantes, com taxas variáveis segundo as modalidades de depósito. No entanto, esse benefício foi abolido há mais de 30 anos pelo Banco Central, com a Resolução $\mathrm{n}^{\mathrm{o}} 15$, de 28.01.1966, de modo que na atualidade nenhum tipo de renda percebe o correntista pelo saldo credor que apresentar sua conta. Ao contrário, pela manutenção do depósito e a sua guarda, costumam os Bancos cobrar mensalmente determinada taxa, cuja variabilidade, ou até a sua isenção, resta na dependência do correntista manter outras operações com a instituição bancária.

Quanto à natureza dessa operação bancária, controvertem os autores sobre a análise de três teorias: a do depósito irregular, a do mútuo e a do contrato típico ou sui generis. A primeira, do depósito irregular, é inaceitável, porque a regularidade do contrato de conta corrente está patenteada pelas obrigações recíprocas que decorrem da própria contratação. Quanto à teoria do mútuo, também não merece melhor sorte, já pelo simples fato de que este caracteriza-se por ser uma operação ativa dos Bancos, enquanto a conta corrente é uma operação passiva. Destarte, afastadas a primeira e a segunda teorias propostas, convergem os autores no sentido de admitir a teoria do contrato típico ou "sui generis", tendo em vista que nesta última a instituição bancária exerce as funções de captadora, guardiã e emprestadora a outros clientes dos fundos depositados pelo poupador de capitais, beneficiando-se este com a segurança que resulta da guarda de suas economias pelo Banco. É esta a idéia que pessoalmente concebemos sobre o tema, embora não exatamente coincidente com a expressada por certos autores especializados. ${ }^{40}$

As modalidades da operação de conta corrente classificavam-se, no passado, quanto ao escopo econômico pretendido pelo depositante, quanto à forma e quanto à titularidade do depositante. Na primeira, os depósitos podiam ser classificados em à vista ou a prazo. O depósito à vista que é a modalidade praticada na atualidade e que interessa ao depositante, ou seja, é aquela, cujo saldo credor pode a qualquer momento ser sacado pelo correntista. Por outro lado, o depósito a prazo, cuja disponibilidade só ocorria após o decurso de certo tempo, não é mais, na atualidade, interessante ao correntista, devido ao período inflacionário por que passa a nossa economia, tendo em vista haver sido absorvido ou substituído pelas

39 MARTINS, Fran. Contratos e Obrigações Comerciais, cit., nº 385, p.433-434.

40 Sobre esse tema, v. Nelson Abrão, Direito Bancário, cit., nº 40, p.110-112. 
atuais aplicações financeiras, que ensejam maiores rendimentos. ${ }^{41}$

Quanto à forma, a operação de conta corrente podia ser classificada, também no passado, em simples ou de movimento. Simples, era aquela em que o ingresso do depósito e a sua retirada realizou-se em uma só vez, encontrando-se atualmente superada em razão da realidade econômica vigente. A conta corrente de movimento é a que permite fluxo contínuo de ingressos e retiradas, estas mediante a emissão de cheques pelo correntista, a qual continua a ser utilizada na atualidade.

Quanto a titularidade da pessoa ou pessoas intervenientes na operação de conta corrente, o depósito pode ser individual ou em conjunto. Individual é aquele em que uma só pessoa intervém na operação, quer seja para depositar ou retirar a quantia depositada.

Em conjunto é a operação de conta corrente que tem no pólo ativo vários depositantes, subdividindo-se esta em simples e solidária. Configura-se como simples a operação de conta corrente conjunta, quando a um dos depositantes é permitido retirar, individualmente, a quantia correspondente à sua quota, sendo que o total depositado só pode ser retirado por todos em conjunto. Solidária é a operação de conta corrente mais usual, na qual é permitido a cada depositante retirar individualmente a integralidade do depósito, situação que libera o Banco depositário integralmente da responsabilidade pelo depósito perante todos os depositantes, como proclama a doutrina italiana ${ }^{42}$ e igualmente a nossa. ${ }^{43}$

Assim sendo, nesta última modalidade de contrato de conta corrente conjunta e solidária a morte, a incapacidade ou a ausência superveniente de um ou mais depositantes solidários não desfaz a solidariedade ativa e não impede que um ou alguns exerçam o direito de todos.

O negócio jurídico referido exige, para sua realização válida, como regra, agente capaz. No entanto, desde a edição do Decreto $n^{0}$ 24.427, de 1934, estavam os menores relativamente incapazes autorizados a abrir e movimentar contas de depósito em Caixas Econômicas, a partir dos 16 anos. Essa situação foi modificada com a edição do Código Civil de 2002, que reduziu a maioridade plena para 18 anos, mantendo a menoridade relativa entre 16 e 18 anos. Modernamente, essa situação de menoridade relativa vem comportando maleabilidade, em face de circunstancialidades da vida moderna, de modo que vem se tornando habitual a prática dos pais ou responsáveis prestarem assistência financeira a seus filhos, autorizando-os a abrirem e movimentar contas correntes bancárias, sem a presença e assistência paterna.

Quanto ao tempo de vigência da conta corrente bancária, é preciso notar

41 Sobre o assunto, v. Nelson Abrão, Direito Bancário, cit., n 43, p.117-119.

42 MOLLE, Giacomo. I Contratti Bancari, p.129-130, Milão, 1973.

43 ABRÃO, Nelson. Direito Bancário, cit., nº 43, p.117-119. 
que a nova lei civil estipula no artigo 205 da codificação, que a prescrição geral é de 10 anos, em relação a todos os direitos que não disponham de regra especial para esse fato prescritivo. No entanto, existe a regra especial da Lei 370, de 04.03.1937 e seu Regulamento pelo Decreto $\mathrm{n}^{\mathrm{o}} 1.508$, de 17.03.1937, que consideram abandonados os valores em depósito, quando restarem inativos durante 30 anos, caso em que devem ser recolhidos ao Tesouro Nacional. É que a guarda dos depósitos por largo tempo gera despesas acumuladas aos Bancos, não se podendo conceber que essa situação venha a acontecer pelo abandono ou descaso do depositante, em dinamizar sua conta corrente bancária, reduzindo-a à inatividade.

Por fim, há que se aduzir que ao depositante em desacerto com o Banco depositário a respeito do saldo credor de sua conta corrente, confere a lei a providência da prestação de contas e bem assim a jurisprudência atualmente consolidada na Súmula 259, do S.T.J.

\section{DO CONTRATO DE REDESCONTO DE TÍTULOS}

É outra operação passiva, dentre as demais operações principais, essenciais ou fundamentais da atividade bancária. O redesconto de títulos de crédito configura, em realidade, uma segunda operação de desconto que um Banco descontário realiza perante outra instituição bancária, tendo por objeto títulos de crédito emitidos por seus clientes, já anteriormente descontados pelo primeiro. A instituição bancária que realiza a operação de redesconto denomina-se redescontante e redescontário o Banco que acolhe esse negócio jurídico.

Anteriormente realizada pela Carteira de Redescontos do Banco do Brasil, autorizada pelo Decreto-lei $\mathrm{n}^{\mathrm{O}}$ 6.634, de 27.06.1944, a operação de redesconto é atualmente da competência exclusiva do Banco Central do Brasil, segundo disposição expressa no artigo 10, inciso IV, da Lei ${ }^{\circ}$ 4.595/64, estando dita operação interbancária regulamentada pelas Resoluções $n^{\circ}$ 2.308/96, 2.727/96 e 2.869/99, expedidas pela mencionada autarquia federal.

$\mathrm{O}$ redesconto caracteriza-se, destarte, como típico negócio jurídico realizado entre Bancos, no qual a instituição redescontante objetiva geralmente obter maior liquidez financeira para implementar o cumprimento de suas obrigações passivas. Assim sendo, em face dos objetivos que o determinam, $o$ redesconto pode receber a classificação de redesconto de liquidez ou de assistência financeira à instituição bancária redescontante.

As taxas de juros remuneratórios do Banco redescontário a que está sujeita a operação de redesconto obedecem os parâmetros estabelecidos pelo sistema SELIC (Sistema Especial de Liquidação e de Custódia), em reuniões periódicas do COPOM - Comitê de Política Econômica, vinculado ao Ministério da Fazenda. ${ }^{44}$ 


\section{DO CONTRATO DE APLICAÇÃO FINANCEIRA}

A operação de aplicação financeira é outra espécie de negócio jurídico que se inclui no elenco das operações principais, essenciais ou fundamentais realizadas pelo Banco, no exercício do papel que lhe é próprio, classificada como operação tipicamente passiva, na qual a instituição bancária receptora dos recursos financeiros do aplicador assume perante o mesmo a posição de obrigada ou devedora, devendo restituir ao cliente, em certo prazo, o capital recebido, acrescido da renda produzida no período convencionado.

Assim sendo, é a dita operação formalizada por um instrumento contratual, mediante o qual o aplicador autoriza o Banco a aplicar no mercado de capitais, em ações, títulos da dívida pública e outros, o dinheiro recebido do cliente, com a obrigação de restituí-lo, na forma acima referida, como registra a doutrina comercialista. ${ }^{45}$

\section{DO CONTRATO DE CADERNETA DE POUPANÇA}

A operação de aplicação financeira é outra espécie de negócio financeiro bancário que se formaliza por instrumento contratual com a mesma denominação e que tem por objeto o depósito em dinheiro que o poupador entrega ao Banco, assemelhando-se à conta corrente cre- dora. Constitui, de igual modo, uma operação passiva, na qual a instituição financeira depositária assume a posição de devedora, com a obrigação de restituir ao aplicador, quando este solicitar, o capital aplicado, acrescido dos rendimentos produzidos no período.

Essa operação bancária é definida pela doutrina como "um sistema de captação de recursos populares, incentivado pelo governo, com a finalidade de possibilitar o financiamento de bens móveis de uso durável ou de imóveis". ${ }^{46}$

A conta poupança, embora apresente similitude com a conta corrente credora, dela se distingue, porque enquanto esta não gera nenhum rendimento ao depositante, aquela é remunerada com um percentual de juros de $0,5 \%$ ao mês, acrescida de correção monetária, ocorrida em sua data base, chamada popularmente data de aniversário, que se verifica no mesmo dia do mês subseqüente ao do depósito.

A operação de caderneta de poupança apresenta certas vantagens ao poupador, pois, além de preservar o capital aplicado contra a desvalorização do padrão monetário e de beneficiar-se da renda por ela produzida no período convencionado, ainda atende a uma relevante função social, qual a de possibilitar o financiamento de imóveis destinados à aquisição da casa própria pelos que dela carecem, inicialmente realizada pelo Banco Nacional da

45 COELHO, Fábio Ulhoa. Manual de Direito Comercial, p.448-451, 16.ed., Saraiva, São Paulo, 2005.

46 ABRÃO, Nelson. Direito Bancário, cit., nº 43, p.117-119. 
Habitação (BNH) e, a partir do Decreto-Lei $n^{\circ} 2.291 / 86$, pela Caixa Econômica Federal, em sua maioria.

A operação bancária desta espécie, que tem a função de receber e administrar os recursos financeiros amealhados pelo público em geral, figura entre os investimentos mais utilizados em nosso País, especialmente pela segurança que proporciona aos aplicadores, pois além de garantir rendimento fixo, não verificado em outros investimentos, ainda preserva o capital aplicado das oscilações ocorrentes no mercado de capitais. ${ }^{47}$

\section{DAS OPERAÇÕES ACESSÓRIAS OU COMPLEMENTARES DOS BANCOS}

Por fim, considerada a classificação das operações bancárias, segundo a sua natureza, em operações principais, essenciais ou fundamentais do comércio bancário, subdivididas estas em operações ativas e passivas, acima examinadas, resta examinar-se as que o Banco realiza, como atividade acessória ou complementar, nas quais a instituição bancária não concede empréstimos, nem recebe capitais do público em geral, mas tão somente assume o encargo de prestação de serviços aos seus clientes. Tais operações são, dentre outras, as que dizem respeito à ordem de pagamento, à co- brança de títulos, à locação de cofres de segurança, à custódia de valores e títulos.

\section{DO CONTRATO DE ORDEM DE PAGAMENTOS}

Mediante este contrato de prestação de serviço, o Banco realiza, a pedido de seu cliente, a transferência de uma quantia em dinheiro para outra instituição bancária sediada em localidade diversa, para que esta a entregue à pessoa designada como favorecida da quantia transferida. $\mathrm{O}$ cliente que se utiliza desse modo de transferência de numerário é chamado tomador, enquanto o que a recebe é denominado beneficiado.

A transferência do numerário objeto da ordem de pagamento bancário poderá ser realizada pelos meios de comunicação escolhidos pelo tomador, ou seja, por carta, telegrama ou telefone, segundo o desejo de urgência ou não manifestada pelo tomador. A ordem de pagamento também poderá ser realizada mediante a emissão de cheque sacado contra a instituição bancária, destinatária da transferência, no qual figura como beneficiária a pessoa que deve receber a quantia transferida.

Pela prestação dessa espécie de serviço, o Banco autor da transferência geralmente cobra do tomador da ordem de pagamento determinada taxa pelo serviço prestado. ${ }^{48}$

47 Acerca dessa aplicação financeira, consulte-se também Paulo Maximiliam Wilhelm Schonblum, Contratos Bancários, $\mathrm{n}^{0}$ 5.2.2, p.82-84, Freitas Bastos, Rio, 2005; Celso Marcelo de Oliveira, Manual de Direito Bancário, nº 60, p.405-406, Thomson-IOB, S. Paulo, 2006.

48 MARTINS, Fran.Contratos e Obrigações comerciais, cit., nº 398, p.442. 
Por fim, é de se salientar que esse tipo de serviço bancário vem se tornando mais raro, na atualidade, devido ao dinamismo e operosidade praticamente instantânea que é oferecida pelo sistema de computação.

\section{DO CONTRATO DE COBRANÇA DE TÍTULOS}

Também classificada como prestação de serviço, o Banco realiza a cobrança e, em certos casos, o aceite do devedor, de títulos sacados por seus clientes contra terceiros, sejam representados por títulos não causais, (como as letras de câmbio) ou por títulos cambiariformes, (como as duplicatas de fatura). Em tais casos, o Banco executa dito serviço na qualidade de mero mandatário do sacador dos títulos, que lhe são entregues para esses fins, mediante endosso para cobrança.

$\mathrm{Na}$ execução desse encargo recebido do seu cliente, o Banco age como simples intermediário entre o sacador (credor do título) e o sacado, (devedor) e obrigado ao pagamento do mesmo, no vencimento.

Para o exercício desse mister, geralmente o Banco fá-lo gratuitamente ou cobra determinada taxa proporcionalmente ao seu valor. ${ }^{49}$

\section{DO CONTRATO DE LOCAÇÃO DE COFRES DE SEGURANÇA}

A locação de cofres de segurança configura uma locação de coisa que o Banco realiza com seus clientes, mediante a qual o locador assegura ao locatário a invulnerabilidade do cofre posto à disposição deste, para a guarda de valores, objetos de estimação ou de grande valia. Trata-se de contrato bilateral, por implicar obrigações de ambos os contratantes, oneroso, por envolver prestações recíprocas e de execução continuada, devido ao seu uso e utilidade prolongada no tempo.

A par dessas características, esse contrato é também chamado locação de cofre-forte, sendo definido pela doutrina como "aquele pelo qual o Banco coloca à disposição do utente um compartimento ou cavidade para a guarda de dinheiro, objetos preciosos ou documentos, mediante remuneração", cuja segurança resulta dos fatores da vigilância e do segredo. ${ }^{50}$

O referido compartimento, no interior do qual são depositados os bens mencionados, o qual constitui o objeto mediato do contrato, é munido de uma fechadura que não pode ser aberta senão com o concurso de duas chaves

49 RODIÊRE, René e RIVES-LANGE, Jean-Louis. Droit Bancaire, cit., p. 188; MARTINS, Fran. Contratos e Obrigações Comerciais, cit., nº 309, p.442; ABRÃO, Nelson. Direito Bancário, cit., nº 114, p.257-258.

50 ABRÃO, Nelson. Direito Bancário, cit., nº 108, p. 247; DE OLIVEIRA, Celso Marcelo. Manual de Direito Bancário, nº 73, p.426, Thomson-IOB, São Paulo, 2006. 
diferentes, uma mantida em poder do Banco e a outra sob a guarda do usuário.

Devido ao dever de vigilância e sigilo que o incumbe com vistas à segurança desse serviço, desconhece o Banco o conteúdo do depósito feito unilateralmente pelo cliente, de modo que tornase realmente difícil estimar ou quantificar o valor dos bens, no caso de destruição ou qualquer outro ato de violência que ofereça ou faça desaparecer as coisas que nele se encontram depositadas. Diante dessas eventualidades, os Bancos costumam fixar valores limítrofes de sua responsabilidade. ${ }^{51}$

\section{CONTRATO DE CUSTÓDIA DE VALORES E TÍTULOS}

Esse tipo de operação acessória ou complementar do Banco, também simplesmente chamada guarda, abrange a custódia de valores e títulos entregues à instituição bancária pelo seu cliente, para serem por aquela guardados, conservados e administrados, com a segurança que é a pedra de toque dessa entidade empresária. Nessa operação revelam-se interesses, recíprocos das partes, pois se de um lado reside o interesse do Banco de prestar o serviço ao cliente para mantê-lo no âmbito de sua atividade empresarial, potencialmente interessado nas operações financeiras que realiza; de outro lado configura-se o interesse do cliente de guardar e manter os bens custodiados sob a administração segura da instituição bancária que dispõe de instalações adequadas, as quais infundem a credibilidade e a segurança pretendida pelo custodiante. ${ }^{52}$

A custódia figura entre as mais antigas operações acessórias dos Bancos, consistente, segundo a doutrina, no fato de alguém confiar à instituição bancária, em depósito, títulos e outros valores móveis, ficando responsável pela boa guarda desses valores depositados. Por vezes, podem as partes convencionar a administração dos bens custodiados pelo Banco e, neste caso, essa instituição custodiante se encarregará de praticar a cobrança de dividendos das ações e o recebimento de juros dos títulos, produzidos por esses bens custodiados. ${ }^{53}$

Dessa operação acessória dos Bancos decorre uma duplicidade de obrigações para as partes. O Banco está vinculado a obrigações de fazer e não fazer, quais sejam, a de custodiar e preservar a coisa, devolvê-la ao custodiante no prazo convencionado ou por este reclamado e bem assim a obrigação negativa de não usar a coisa. O cliente, por outro lado, resta obrigado a ressarcir o Banco das despesas realizadas com a guarda dos valores e títulos custodiados. ${ }^{54}$

51 MAXIMILIAN, Paulo e SEHONBLUM, Welhelm. Contratos Bancários, nº 5.11.4.2, p.260-261, Freitas Bastos, Rio de Janeiro, 2005.

52 ABRÃO, Nelson. Direito Bancário, cit., n n s 102 a 105, p.236-243; DE OLIVEIRA, Celso Marcelo. Manual de Direito Bancário, cit., $\mathrm{n}^{\circ}$ 72, p.425-426.

53 Sobre o assunto, v. Fran Martins, Contratos e Obrigações Comerciais, cit., nº 400, p. 442. 54 ABRÃO, Nelson. Direito Bancário, cit., nº 104, p.237-241. 